\title{
GAIN-BASED REMEDIES FOR KNOWING ASSISTANCE: Ensuring ASSistants do nOt Profit From Their Wrongs
}

\author{
MYSTY S. ClaPTON ${ }^{*}$
}

The article examines the availability of gain-based remedies for the equitable uromg of knowing assisfance. After separately considering the mature of gain-baved remedies and the canse of action in knowing assistance. the author concludes that knowing assisfance is capable of supporting personal gain-based rulicf. The author also concludes that the source of the gain and the nature of the underlying relationship between the wrongdoing assistant and innocent beneficiary do not support a proprietary gain-based remedy.
$L$ article porte sur la disponibilité de recours, basés sur le gain, au mal diquitable de " knowing arsistance ». Après awoir examiné sćparémem la nature des recour: basés sur le gain ef la cause daction dans la connaissance du mol, l'autetur conclut que celte comnaissance peut soulenir laide personnelle basée sur le gain. L'auteur conclut aussi que la source du gain et la nature de la relation sous-jacente enre ladjoint qui fait le mal et le bènéficiaire innocent ne constitue pas un recours special basé sur le gain.

\section{TABLE OF CONTENTS}

I. INTRODUCTION . . . . . . . . . . . . . . . . . . . . . 989

II. GAIN-BASEd REMEdIES For WRONGS . . . . . . . . . . . . . . 990

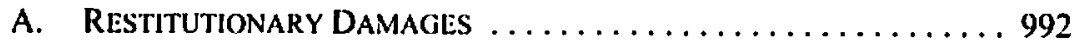

B. Disgorgement Damages . . . . . . . . . . . . . 993

C. GaIn-Based Proprietary Remedies ... . . . . . . . . . . 996

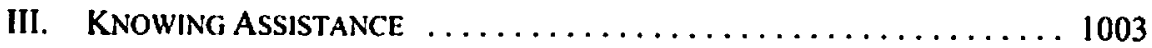

A. The "Constructive" TrusteE . . . . . . . . . . . . 1003

B. BASIS OF LIABILITY FOR

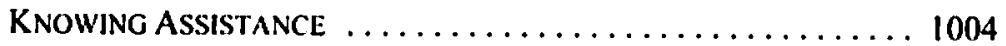

IV. GAIN-BASED LIABILITY OF THL:

KNOWING ASSISTANT . . . . . . . . . . . . . . . . . . . . 1009

A. JOINT AND SEVERAL LIABILITY FOR

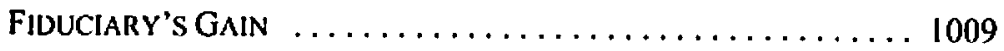

B. LIABILITY FOR DEFENDANT's GAINS . . . . . . . . . . 1010

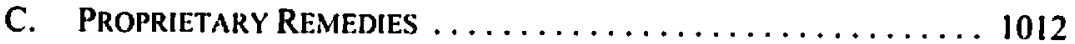

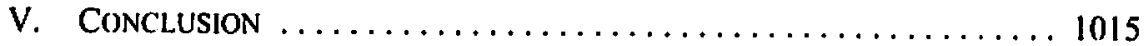

\section{INTRODUCTION}

In recent years, gain-based remedies have received an increasing amount of attention from scholars and the judiciary. While gain-based remedies are certainly nothing new, these awards have increasingly been scrutinized as lacking a coherent theoretical framework and as obscuring the principles of unjust enrichment and restitution. The aim of this article is to provide a framework for awarding gain-based remedies for a specific equitable wrong: knowing assistance. In doing so, it will be necessary to consider the nature and availability of gain-based remedies, the nature of the cause of action in knowing assistance, and of 
course, whether remedies measured by the defendant's gain should be available for this species of equitable wrong.

To that end, the discussion that follows consists of three principle parts. The first part considers, in somewhat abstract terms, the nature of gain-based remedies for wrongs, some of the problems with their current conceptualization, and how they should be conceptualized. In brief, I consider the explanation recently elucidated by James Edelman' that gain-based damages should be divided into two categories - restitutionary damages and disgorgement damages - in order to avoid confusion when awarding relief measured by the defendant's wrongful gain. This distinction provides a useful framework for understanding the nature of the liability of the knowing assistant. This part also makes some important preliminary observations about the availability of proprietary gain-based remedies for equitable wrongs.

The second part of the discussion makes general observations about the cause of action in knowing assistance. It examines the nature of the underlving relationship, the elements required to establish the equitable wrong, and the substantive basis for imposing liability against a stranger to the trust.

The heart of this article lies in the third principle part which considers the intersection between gain-based remedies and knowing assistance. 1 arguc that knowing assistance is a form of equitable accessory liability which explains and justifies the availability of disgorgement damages. I go on to analyze the problem encountered when the plaintiff seeks a proprictary gain-based remedy (constructive trust) against the knowing assistant. In Canada, such relief has long been available against the fiduciary. Recently, however, the British Columbia Court of Appeal granted the same remedy against a knowing assistant. However, I conclude that the source of the gain and the nature of the underlying relationship between the wrongdoing assistant and innocent beneficiary does not necessarily support a proprietary gain-based remedy.

\section{GAIN-BASEd Remedies fOR Wrongs}

This section takes as its starting point the view that the law's normal response to a wrong ${ }^{2}$ is to create for the victim a personal right to the payment of money, usually in the form of

Gain-Based Damages: Contract. Tort, Equity and Intellectual Property (Oxford: Hart, 2002).

A wrong, for the purposes of this article. is an act or omission on the part of the defendant that is characlerized as the breach of a primary duty. The primary duty may originate from the common law, such as statutory breach, the conmission of a tort or a breach of contract, or from equity, such as the breach of a fiduciary duty. The view of some authors is that the acquisition of profits by a fiduciary is not wrong-based liability, but inslead stems from a rulc disabling the fiduciary from kecping any profits for himself. Disability-based liability finds influential support from Lord Millett. Sec Lord Millett, Book Review ol Gain-Based Damages: Comtract, Fort. Equily' and/nelle'shal Property by James Edelman. (2002) 2 O.U.C.L.J. 291 at 295: Peter Millelt. "Proprietary Restitution" in Simone Degeling \& James Edelman, eds., Equity in Commercial Law. (Sydney: Law Book, 2005) 309 at 324. The predominant view in Canada, however, is that fiduciary liability for gains made in breach of duty is wrong-based. See International Coroma Resources Lid. v. Lac Minerals LAd. (1987), 62 O.R. (2d) I at 55-56 (C.A.), alfd [1989] 2 S.C.R. 574 [I.ac Minerals]. 
monetary damages, ${ }^{3}$ and a correlating obligation on the wrongdoer to pay those damages. The usual measure of damages is compensatory, which is measured by the victim's loss, subject to limiting principles, such as remoteness. For its part, loss-based relief can be measured in more than one way. Consider the distinction between contract and tort. On one hand, compensation for breach of contract is forward-looking insofar as it (usually) attempts to put the plaintiff in the position she would have been in had the defendant performed his duties as agreed. Compensation for tort, on the ollher hand, is backward-looking insolar as it attempts to put the plaintiff in the position she would have been in had the tortious act not been committed. Both measures of compensation provide reparation for the plaintiff's loss, but they do so in reaction to different primary duties. Notwithstanding the differences, both forms of loss-based damages attempt to make the victim whole, as far as money can do.

In some circumstances, the plaintiff may receive an award measured by the defendant's gain. There may be several reasons for pursuing a gain-based remedy, including the possibility that the plaintiff cannot establish a loss. but she can nevertheless prove that a wrong has been committed against her for which the defendant acquired a benefit. Even in situations where the plaintiff can establish a loss, it may be that the defendant would nevertheless retain a profit from his wrongdoing even after payment of a compensatory award. In such circumstances, the plaintiff may wish to elect gain-based damages to ensure that the wrongdoer does not profit from his wrong. Whatever the case may be, like loss-based damages, gain-based damages can conceivably be measured in more than one way.

As mentioned above, Edelman has recently put forth a comprehensive theory regarding gain-based damages for wrongs that stems from a taxonomic view of private law championed by Peter Birks. ${ }^{4}$ This taxonomy divides private law into causative events and legal responses. Causative events - events which give rise to causes of action in law and equity - include unjust enrichment, wrongs, consent, and miscellaneous others. Each of these causative events support various legal responses or remedies. A wrong, for instance, may support several legal responses, including the payment of monetary damages, a proprictary remedy such as a constructive trust, or an equitable remedy such as an injunction.

The most significant contribution from Edelman's thesis is the distinction it draws between two varieties of gain-based damages for wrongdoing: restitutionary damages and disgorgement damages. This distinction is helpful for the purposes of this article because it brings into sharp focus the source of the defendant's gain. Briefly put, restitutionary damages are limited to those benefits wrongfully acquired from the plaintiff, whereas disgorgement damages include any gain that the defendant received as a result of committing a wrong

Although the point is not without some controversy, it is the position in this article that the term "damages" encompasses all monetary forms of relief for wrongdoing (including punitive and nominal damages) and is not conlined to compensalory damages measured by the victim`s loss. Sec Ldelman, supra note 1 at 6-23. Cf. Altorney-Gieneral 1: Blake, [2000] 3 W.L.K. 625 (H.L.) at 638: Harvey MeGircgor. "Restitutionary Damages" in Peter Birks. ed.. Wrongs and Remedies in the Tivemin-First C'mury (Oxford: Clanendon l'ress, 1996) 203.

$+\quad$ Sec e.g. Peter Birks, "Equity in the Modem Law: An Lxercise in Taxomony" (1996) 26 U.W.A. I. Rev. 1: Peter Birks, "Misnomer" in W.R. Cornish et al., eds., Restitution: Past, Present and fiumere: Essans in Honour of Gareth Jomes (Oxford: Hart, 1998) I: Professor Peter Birks. "This Heap of Good Leaming: The Jurist in the Common Law Tradition" in Basil S. Markesinis, ed., Law Making, Law Finding and Law Shaping: The Diverse Im/luences (Oxford: Oxlord University Press. 1997) 113. 
against the plaintiff. So, while restitutionary damages are only capable of stripping gains that the defendant acquired from the plaintiff, disgorgement damages are able to strip gains acquired from any source, including, but not limited to, the plaintiff. The following subsections consider these two forms of gain-based damages in more detail.

\section{A. Restitutionary Damages}

Restitutionary damages operate to reverse a wrongful trans fer of value from the plaintiff's assets. 'In other words, this form of damages requires the defendant to give back the value of the benelit he subtracted from the plaintiff in the course of committing a wrong against her. The rationale for reversing such a transfer is that it was obtained by a wrongful act and, as such, it is not a transfer that should be recognized in law. As a matter of corrective justice, the law must respond in this way - that is, reverse a transfer of value acquired through wrongful conduct - because to do otherwise would be to condone such behaviour. ${ }^{6}$

This form of gain-based damages is often conflated with the monetary award of restitution that is awarded to the successful plaintiff of an unjust enrichment action. ${ }^{7}$ The confusion comes as no surprise since both restitution for unjust enrichment and restitutionary damages operate the same way insofar as they force the defendant to give back the value of the benefit he received from the plaintiff.' In other words, each measure of damages responds in the same way, but what they respond to is quite different. Restitution and restitutionary damages are awarded in response to different causative events. The former award may be granted if the plaintiff can prove the three elements of the autonomous action in unjust entichment. The latter may be awarded if the plaintiff can prove that the defendant perpetrated a civil wrong against her and, in doing so, subtracted or transferred a benefit from her.

This problem - the failure to differentiate between restitution for unjust enrichment and restitutionary damages for wrongdoing - has led to conceptual difficulties and a failure to properly respond to the underlying cause of action. The Supreme Court of Canada decision

To relier to restitutionary dlamages as "gain-based" is somew hat of a misnomer. Restitutionary damages are not strictly gain-based; like restitution for unjust enrichment, they are loss-based as well, insofar as the transfer of value to the deliendant causes the plaintift a loss.

lidelman, supra note 1 at $80-81$.

The three part cause of the iulonomous action in unjust enrichment is set out in Pettkus v. Becker. (1980] 2 S.C.R. 834 at $848 \mid P$ etrkus]. It requires (1) an enrichment to the delendant, (2) a corresponding deprivation to the plaintifl, and (3) the absence of any juristic reason for the enrichment.

According to Edelman's account, restitution and restitutionary damages are virtually identical concepts that respond to different underlying causes of action. Both reverse a transfer between the parties. The former responds to an action in unjust enrichment, whereas the latter responds to any civil wrong that entails a transfer. In cither event. however, the implications of those remedies are different in Canada than elsewhere in the Commonwealth. Canadian law caps restitution (and presumably restitulionary dannges) by the highest anount common lo the defendant's ultimale gain and the claimant's ultimate deprivation. The meassure of reliel inccordingly is reduced to the extent that, following a transfer, the defendant experiences a change ol position or the claimant shifts the expense onto a third party: Air Camada v. British Cohumbia, [1989] I S.C.R. 1161 at 1202-203; cf. Kingstreet Imvestments Lud. : New Brumswick (Finance), 2007 SCC 1, [2007] I S.C.R. 3. In contrast, the claimant's expense is relevant only insofiar as it creates the standing to sue. Once that hurdle is crossed by proof of a transfer between the parties, the measure of restitution may be reduced hy the defendant's change of position, but not by any diminishment to the claimant's eventual expense. 
in Lac Minerals ${ }^{9}$ illustrates the sort of conceptual confusion that may arise. In that case, the Court confused disgorgement for wrongs with restitution for unjust enrichment. ${ }^{10}$

\section{B. DisGorgement DaMageS}

Disgorgement damages operate to strip or disgorge gains that the defendant acquired through wrongdoing. The distinguishing feature of disgorgement damages is that they ignore whether the gain has been transferred from the plaintiff's assets and, instead, measure the actual profit accruing to the defendant from his wrongful behaviour regardless of the source." The phrase "account of profits" is often used to describe the obligation that is imposed on the defendant to pay the value of his gain to the plaintiff. ${ }^{12}$

\section{THE NATURE OF Disgorgement DAMAGeS}

According to Edelman, the primary objective of disgorgement is deterrence, ${ }^{13}$ which discourages wrongful behaviour by engendering fear of liability and, more specifically, strips away and hands over the profits or gains to the plaintiff.'4 That is to say, the defendant will be less inclined to breach the duties he owed to the plaintiff if the benefit that he would acquire from doing so would get taken away. Disgorgement, through its deterrent function, seeks to prevent individual and institutional harm by ensuring that no one profits from his wrong.

Since the law generally does not allow a person to profit from his own wrong, it will compel the wrongdoer to give up the gain he received, regardless of its source. This gives rise to the possibility that disgorgement damages may make the plaintifl better off than she was before the wrong. Where, for instance, the plaintiff does not suffer any loss, and the defendant's gains are not the result of an impugned transfer from the plaintiff, an award of disgorgement will provide the plaintiff with a windfall. The tension between those conflicting principles is resolved by practical considerations. First, as between the two parties, it is more

- Supra note 2. crilicized in Mitchell Mcinnes, "The Canadian Principle of Unjust Enrichment: Comparative Insights Into the Law of Restitution" (1999) 37 Alta. L. Rev. 1 at 28-31; Lionel D. Smith, "The Provinee of the Law of Restitution" (1992) 71 Can. Bar Rev. 672 at 692.

Justice Sopinka made the same conceptual crror in his dissent in Soulos v. Korkomzilas, [1997] 2 S.C.R. 217 [Soulos].

"Edelman, supra note 1 at 72 .

1: The phrase "account of profits" may be defined in other ways as well. It can, for instance, describe the process by which the defendant 's financial accounts are assessed to determine the extent of the benefit he acquired vis-à-vis the plaintiff. See generally Mitchell McInnes, "Account of Profits for Common Law Wrongs" in Degeling \& Edelman. stupra note 2, 405.

Edelman, supra note I at 81-86. Sec also Mitchell Melunes, "Disgorgement for Wrongs: An Experiment in Alignment" [2000] R.L.R. S16 at 534: Mitchell Mcinnes, "Interceptive Subtraction, Unjust Enrichment and Wrongs - A Reply to Professor Birks" (2003) 6 Cambridge L.J. 697 at 706 [Mclnnes. "Subtraction"]; Craig Rotherham. "Proprictary Relief for Lnrichment by Wrongs: the Shifting Houndary between Ownership and Obligation" in Craig Rotherham, Proprie'cury Remedies in Context: A Situdy in the Sudiciat Redistribution of Property Rights (Oxford: Ilart, 2002) 177 at 178.79.

It The view that disgorgement damages have the ability to deter wrongs is not universally accepted. For example, an attentive wrongdoer may discount the amount of anticipated liability by the probability of being held liable. 'Therefore, if' the wrongdoer perceives there to be a one in ten chance of liability, damages must be increased tenfold to adequately deter the behaviour. In the context of tort law, sec Bruce Feldthusen, "Punitive Damages: Hard Choices and High Stakes" [1998] N.Z.L. Rev. 741 at 751. 
in keeping with broad notions of justice that the plaintifr should acquire the gain rather than the defendant. Second, a potential windfall may encourage the plaintiff to sue in a situation where she would not otherwise be motivated to do so (that is, because she only would receive nominal damages at best). By bringing the wrongdoer to justice, the plaintiff helps protect the integrity of the underlying cause of action..$^{\text {is }}$

The deterrent function of disgorgement can operate to prevent two different types of harm. First, to the extent that the actions of the would-be wrongdoer causes harm to an individual, the threat of disgorgement may prevent harm to that individual. Individual harm is usually remedied by compensation; however, there may be circumstances in which disgorgement is necessary to prevent the harm altogether. For example, an agent may use his position of trust and confidence to take a benefit that he would not otherwise have acquired. Assuming that the breach of confidence produces a greater gain for the agent than it creates a loss for the principal, the agent may deliberately decide to breach his duty of confidence if the plaintiff s remedy is limited to compensation. Even though an award of compensation would make the plaintiff whole again, that type of award may not adequately deter the wrongdoing agent from causing harm to the plaintiff in the first place. If the wrongdoer still stands to gain something from his wrongful act, he may decide to carry through with it. However, if the wrongdoing agent is required to disgorge the whole of his profits, there is greater likelihood that he will not breach his duties because there is nothing to gain in doing so. It is in this way that the deterrent function of disgorgement can prevent individual harm.

In preventing harm to the individual plaintiff, disgorgement necessarily prevents a second type of harm - institutional harm. To the extent that private legal institutions, such as equitable relationships of trust and confidence, require protection from wrongful interference, the deterrent or "prophylactic" function of disgorgement operates to protect those institutions. ${ }^{16}$ Consider the fiduciary relationship; a fiduciary is someone who has undertaken to act for or on behalf of another in circumstances that give rise to a relationship of trust and confidence. The fundamental obligation of a fiduciary is the obligation of loyalty. ${ }^{17}$ Stemming from this core obligation, there are general duties for the fiduciary not to place himself in a position where his duty and interest may conflict and to refrain from using his position to make unauthorized profits. ${ }^{1 \times}$ Where he has done so, he will be required to disgorge unauthorized profits. ${ }^{19}$ It is not a defence that the fiduciary was acting bona fide and in the best interests of the principal. Liability arises from the mere fact that a profit has been made. The fiduciary, however well-intentioned and honest, cannot avoid having to disgorge his gain. ${ }^{20}$ In other words, even where the fiduciary's actions generate a profit for the

$15 \quad$ McInnes, "Subtraction," supra note 13 at 706.

16 See I.M. Jackman. “Restitution for Wrongs" (1989) 48 Cambridge L.J. 302.

17 Canadian Aero Senvice Lid. v. O'Malle', [1974] S.C.R. 592 [Canadian Aero Service].

18 Other obligations include the duty to act in good faith and to avoid acting for his own benefit or the benefit of a third party without the informed consent of the principal.

14 Canadian Acro Sirvice, supra nole 17; Regal (I/astings) LAl. 1. Gilliver, [1967] 2 A.C. I34 (H.L.): Bourdman v. Phips. [1967] 2 A.C. 46 (H.L.); Cook v. Decks, [1916] I A.C. 554 (P.C.); Hospilul Products l.td. v. Unired States Surgical Corporation, [1984] HCA 64, 156 C.L.R. 41.

20 It stands to reason that the dishonest fiduciary - one that deliberately and cynically uses his position for profit or one that receives a bribe or secret commission - should also be required to account to the principal for his gain. See Soulos, supra note 10; Reading v. Altorney-General, [1951] A.C. 507 (H.L.) [Reading]; Altorney-General for Ilong Kong v. Reid. [1994] 1 A.C. 324 (P.C.) [Reid]. Whether the 
principal and fiduciary alike, the fiduciary will be required to hand over his gains. In such circumstances, the purpose of disgorgement is not so much the deterrence of individual harm to the principal (because there is none); rather, disgorgement is aimed at preserving the integrity of the fiduciary relationship and avoiding institutional harm. ${ }^{21}$ It is the need to safeguard the vulnerability of relationships of trust and confidence that necessitates this level of institutional protection.

Now that we have considered why we may wish to award disgorgement damages, we now turn to consider when disgorgement damages should be awarded.

\section{The AVAILABILITY OF DISGORGEMENT DAMAGES}

Knowing that disgorgement seeks to deter wrongs by stripping ill-gotten gains, it follows that disgorgement damages should be available when other measures of damages do not provide sufficient deterrence. This position accords with Edelman's position that the deterrent effect of disgorgement damages is necessary when compensatory damages are inadequate. Edelman argues that this occurs in two situations: (1) when wrongs are committed deliberately and cynically, and (2) when the defendant breaches a fiduciary duty."2

The first type of situation is apt to occur quite frequently since it applies whenever the defendant deliberately or recklessly commits a wrong with the hope or expectation of acquiring a material gain. ${ }^{23}$ One might argue that this type of deliberate behaviour can be adequately deterred through an award of punitive damages. ${ }^{24}$ In Whiten v. Pilot Insurance, ${ }^{25}$ the Supreme Court of Canada outlined a series of factors to consider for awarding punitive damages, including the "wrongful profit" factor, which states that "it is rational to use punitive damages to relieve a wrongdoer of its profit where compensatory damages would amount to nothing more than a licence fee to earn greater profits through outrageous disregard of the legal or equitable rights of others." ${ }^{26}$ The Court went on to caution against disgorging profits from the wrongdoer twice - once through an account of profits, and a second time by way of punitive damages. ${ }^{37}$

In Whiten, the Supreme Court of Canada nonetheless stated that the sole purpose of the punitive damages award in that case was to punish the bad faith of the insurer in discharging its duties under what should have been a good faith contract on both sides. ${ }^{2 *}$ Whiten illustrates that wrongful profit is not a necessary requirement for an award of punitive

fiduciary should further be required to disgorge his gain in proprietary form is a question considered in Par IV.C, below.

Jackman, supro note 16 at $313-14$.

Edelman. supro notc I at 84-86.

Jbid. all 85.

On the relationship between disgorgement and punitive damages, see Jeff Berryman. "The Case for Restitutionary Damages Over Punitive Damages: Teaching the Wrongdoer that Tor Does Not Pay" (1994) 73 Can. Bar Rev. 320.

2002 SCC 18. [2002] I S.C.R. S95 [Whiten].

lbid. at para. 72.

Ibid. at para. 124.

lbid. at para. 161. 
damages, but where wrongful profit occurs, it is reasonable to strip that profit through an award of punitive damages.

The better approach where wrongful profit has been made is to isolate the gain and strip it from the wrongdoer through an award of disgorgement damages, reserving punitive damages for exceptional cases of malicious and high-handed conduct. ${ }^{29}$ Separating wrongful gains from the purview of punitive damages and placing them within that of disgorgement damages sends a clear message about the nature of each form of damages. Disgorgement damages, on one hand, do not require high-handed conduct, whereas punitive damages require a level of "misconduct that represents a marked departure from the ordinary standards of decent behaviour" ${ }^{30}$ - something beyond deliberate and cynical behaviour.

The second situation in which compensatory damages do not provide adequate protection and that may occur even though the defendant's breach has not been deliberate or cynical is breach of fiduciary duty. As Edelman points out, "the high degree of institutional protection afforded to fiduciary relationships can be justified as necessary to place the fiduciary on constant alert even to the possibility of innocent breach. Such vigil is necessary in relationships characterised by vulnerability and susceptibility to abuse." ${ }^{31}$ Since the fiduciary has been entrusted with the power to make decisions on behalf of the principal, the fiduciary is charged with the duty to resist self-serving conduct. The deterrent effect of disgorgement damages ensures that the fiduciary fulfills his duty because he knows he has nothing to gain from abusing his position.

\section{Gain-Based Proprietary Remedies}

As previously mentioned, the law's normal response to a wrong is a personal right in the form of monetary damages. There are, however, circumstances in which a monetary award does not produce a satisfactory result, as in the situation when an innocent party pits herself against an insolvent wrongdoer. In that type of case, the personal right to a monetary award may be entirely worthless. It is therefore of considerable interest to the innocent party to know whether she can acquire a proprietary right in assets that the wrongdoer gains through commission of an equitable wrong. ${ }^{32}$

See Edelman, supra nole 1 at 84 . This was the approach taken by the British Columbia Court of Appeal in Insurance Corp. of British Columbia v. L.o, 2006 BCCA 584, 278 D.L.R. (4th) 148 [ICBC].

30 Performance Industries Lid. v. Sy/van Lake Golf \& Tennis Club Lid, 2002 SCC 19, [2002] I S.C.R. 678 at para. 79; Whiten, supra note 25 at para. 36; Hill v. Church of Scientology of Toronto, [1995] 2 S.C.R. 1130 at para. 199; Norberg v. Wynrib. [1992] 2 S.C.R. 226 al 267; Prebushewski v. Dodge City Auto (1984) Lid., 2005 SCC 28, [2005] I S.C.R. 649 at para. 24.

3 Edelınan, stapra note 1 at 85 . See also Grallam Virgo, The Principles of the Lem' of Restitution (Oxford: Clarendon Press, 1999) at 518-19.

1: Following Edelman's thesis, proprictary awards for wrongs mirror personal gain-based damages, which means that there are two typus of proprietary gain-based awards - proprictary restitutionary awards (corresponding to restilutionary damages) and proprietary disgorgement awards (corresponding to disgorgement damages); ibid. al 252 . The availability of a proprictary restitutionary claim for knowing receipt is briefly considered in Part IV.C, bulow. The position of this article is that a proprietary remedy for knowing assistance, il'available at all. is properly eategorized as a proprietary disgorgement remedy. Sec Part IV.C, below. 


\section{AVAILABILITY OF Proprietary DISGORGEMleNt}

The leading case in Canada for determining the availability of a proprictary remedy for equitable wrongdoing is Sotwos. ${ }^{33}$ In that case, the defendant real estate broker, Mr. Korkontzilas, breached his duty of loyalty by failing to notify his client, Mr. Soulos, of a vendor's counter-offer. Instead, the defendant arranged for his wife to purchase the property, an interest in which was later transferred to Korkontzilas as joint tenant. When Soulos learned of the breach, he brought an action to have the property conveyed to him notwithstanding the fact that the property had decreased in value during the period that Korkontzilas held it. Soulos claimed that the property had special value to him beyond any financial value because the property was leased by Soulos' banker, and being the landlord of one's banker would increase the plaintiff's reputation in the Greek community. As such. Soulos had a continuing desire to own the property.

The majority of the Supreme Court of Canada allowed the constructive Irust on the basis that an award of damages would not adequately compensate Soulos. The proprictary award effectively put the plaintiff in as good a position as if the defendant had properly performed his duty by forcing the defendant to hold in trust commercial property that the plaintiff would have acquired but for the defendant's breach of fiduciary duty. ${ }^{34}$ Moreover, a monetary award aimed at stripping the defendant of his profit was inadequate because the property had decreased in value. In order to sufficiently deter similar conduct in the future, the Court found that it was necessary to grant a proprietary right. To do otherwise would allow real estate agents to breach their duties to their clients unless the client could prove that the agent made a profit. 3

Justice McLachlin (as she was then) explained that the touchstone for awarding a constructive trust for an equitable wrong is good conscience:

The inquiry into good conscience is informed by situations where constructive trusts have heen recognized in the past. It is also informed by the dual reasons for which constnuctive trusts have traditionally been imposed: to do justice between the parties and to maintain the integrity of institutions dependent on trust-like relationships. Finally, it is informed by the absence of an indication that a constructive trust would have an unfair or unjust effect on the defendant or third parties, matlers which cquily has always taken into acecount. Equitable remedies are flexible; their award is based on what is just in all the circumslances of the casc. ${ }^{36}$

Relying on an article by Roy Goode, ${ }^{37}$ the majority went on to prescribe four conditions ${ }^{36}$ which should be satisfied before granting a constructive trust. Before considering each of

Supra note 10.

In disgorging the defendant's wronglul gain through the imposition of a constructive trust, the order seems analogous to specific performance for breach of contract. Sec Andrew Burrows. The Low of Resstitution, 2d ed. (London: Butiensorths LexisNexis, 2002) at Sol [Burrows, l.aw].

Sec Edelman, supra note 1 at 264.

Soutox, supra note 10 at para. 34.

Roy (joode, "Property and Unjust Enrichment" in Andrew Burrows, ed. Essongs on the Law of Restitution (Oxford: Clarendon P'ress, 1991) 215 [Goode. "Property"].

Soulos, supra nole 10 at para. 45. For commentary on the Goode/Soulos test, sec Anthony Duggann. "Constructive Trusts and the Deemed Agency Limitation," Case Comment, (2005) 84 Can. Bar Rev. 151. 
these conditions, it is necessary to consider some of Goode's other central propositions which lay the framework for the four conditions. The starting point for his thesis is that a defendant can acquire an enrichment (that is, a gain) in two ways. First, the defendant can acquire an enrichment directly from the plaintiff's estate (that is, enrichment by subtraction). Where the defendant has acquired the plaintiff's property through true subtractive enrichment, the plaintiff will be entitled to a proprietary remedy because the plaintiff has a sufficient proprietary base ${ }^{39}$ in the asset. ${ }^{40}$

The second way that the defendant can acquire an enrichment is by breach of a primary duty owed to the plaintiff (that is, enrichment by wrong). ${ }^{41}$ Goode distinguishes between two kinds of cases. First, there are cases of deemed agency gains; these are cases where the defendant's gain is derived from activity undertaken by the defendant for his own benefit and which, if he pursued them at all, he was under an equitable obligation to undertake for the plaintiff." The second type of case is where the defendant's gain results from an activity that the defendant should have never undertaken at all (for example, taking a bribe). In both types of cases the defendant's gain does not deprive the plaintiff of something she already owns. Significantly, Goode maintains that a proprietary remedy should be awarded only for deemed agency gains - that is, where there is a clear link between the defendani's breach of equitable obligation and the particular asset to which the plaintiff lays claim. This is because the defendant's breach of an equitable obligation deprives the plaintiff of a benefit that would have otherwise come to her but for the breach of duty. ${ }^{43}$ The same cannot be said of a bribe, which would never have come into the hands of the plaintiff under any circumstances. ${ }^{\text {t }}$ The distinction is important for establishing principled parameters for the allocation of proprietary awards. The plaintiff should be entitled to a proprietary award only where there is a preexisting proprietary base or where the plaintiff would have had a proprietary base but for the defendant's wrongful act.

With those preliminary points in mind, we can move on to consider the four prerequisites for the imposition of a constructive trust for equitable wrong. First, the defendant must be under an equitable obligation, such as a fiduciary duty or a duty of loyalty, regarding the activities giving rise to the asset he has acquired..$^{45}$ As Goode explains, the equitable

Goukle, "Property," stupra note 37 at 245 . The plaintiff will have al suflicient proprietary base in one of threc situations:

(1) The asset was itself transferred by the plaintilf to the defendant in circumstances such that the defendant never had, or has lost, the right in it.

(2) The asset represents the identifiable proceeds or product of another assel so transferred.

(3) The delendant intercepts money or property to which the plaintiti had a direct right against a third party.

The proprietary remedy for this type of ease corresponds to Edelman's proprietary restitutionary award: see Edelman, supra note 1 at 261-62.

The proprictary remedy lor this type of case corresponds to Ldelman's proprictary disgorgement award: sce ihid. at 262-64.

Goode. "Property," supra nute 37 at 218.

thid. at 226.

This category of ease is discussed in more detail in Part IV.C.3, below.

The Ontario Divisional Cour recently questioned why common law duties cannot also support the remedy of a consiructive trust in. Serhom Estate v. Johnson \& Johnson (2006), 85 O.R. (3d) 665 at paras. 91-93 (Sup. Ct. (Div. Ct.)), leave to appeal to Ontario C.A. refused, leave to appeal to S.C.C. refused, 31762 (12 April 2007). See also Lionel D. Smith. "Constructive Trusts - Unjust Enrichment - Breach of Fiduciary Obligation: Soulos v. Korkontziles," Case Comment. (1997) 76 Can. Bar Rev. 539 at 545; 
character of the relationship is important because it demands that the defendant "subordinate his interests to those of [the plaintiff] within the ambit of the obligation." breaches of equitable duty will entitle the plaintiff to a proprietary award.

The second condition is that the asset in the hands of the defendant must have resulted from deemed agency activities or actual agency activities. In Soulos, the defendant acquired for himself a benefit which, if he acquired it at all, he should have acquired for the plaintiff. As such, the Court treated Korkontzilas as holding the property on constructive trust for Soulos. This is an application of the general principle that equity treats as done that which ought to be done.

Third, the plaintiff must persuade the court that she has either a legitimate personal reason for a proprietary remedy or such an award is necessary to ensure that others in a similar position as the defendant must remain faithful to their equitable duties. In other words, like disgorgement damages, proprictary disgorgement is aimed at preventing individual and/or institutional harm. Goode identifies several considerations that might motivate a plaintiff to seek a proprietary remedy, including an increase in the value of the asset, the uniqueness of the asset, the difficulty of valuing the asset or its profit potential, and the possibility that the defendant may avoid execution of a monetary judgment by moving his signilicant assets out of the jurisdiction of the court. ${ }^{.7}$ Importantly, Goode insists that the defendant's bankruptcy or impending insolvency does not provide a legitimate reason for seeking proprietary relief. ${ }^{48}$ On the contrary, the defendant's solvency is a concern which falls within the purview of the fourth condition.

The fourth and final condition set out by the Supreme Court in Soulos is that there must be no reason or factor indicating that a constructive trust would be unfair in the circumstances. The clearest case for refusal, according to Goode, is the situation where the

Robert Chambers, "Constructive Trusts in Canada" (1999) 37 Alta. L. Rev. 173 at 182.

Canadian courts have tended to be more open to awarding proprietary disgorgement for equitable wrongs than elsewhere in the Commonwealth. In Lac Minerals, stypra note 2, the Supreme Court of Canada held that a breach of confidence can trigger a proprietary response. Importantly. however. Cadbury Schweppes v: FB/ foods I.td, [1999] I S.C.R. 142 at para. 48, made it clear that not every breach of conlidentiality would automatically support a proprielary remedy. $A$ constrnctive trust was an appropriate remedy in Lac Minerals because of what was likcly lo occur but for the defendant's breach of duty - that is, the plaintifl's would have acquired the gold mine but for the defendant's misuse of confidential information. Accordingly, any measure of monetary relief would not have been sufficient to fully compensate the plaintifl. Moreover, given the difficulty of assessing the delendant's gain, any award of damages would be inadequate to prevent the defendant from profiting from its wrong. The result of the proprietary award in Lac. Mineruls was to put the plaintiff in as good a position as if the defendant had properly performed its duty.

English courts. on the other hand. have steadfastly refused to award proprietary disgorgement in the absence of a breach of fiduciary duty. For instance, in /lalifax Building Socien v. Thomas, [1996] 2 W.L.R. 63 (C.A.), the delendant fraudulently obtained a mortgage from the building society and the Court of $A$ ppeal relused to award a constructive trust over the prolits because, inser wica, the delendant was not a fiduciary. "To that end, Gibson L.J. staled that "there wass no liduciary relationship between Mr. Thomas and the society in respect of the mortgage but merely that of deblor and secured ereditor" (at 72). Occasionally, if the court cannot point to a fiduciary duty, a tiduciary duty may nonetheless be loosely imposed to justify a proprietary remedy: see e.g. Reculing. supra note 20. 
rights of the defendant's creditors are subordinated to the plaintiff as judgment creditor. Proprietary protection in such a case removes an asset from the defendant's estate and therefore may require that the order for a constructive trust be made on terms that avoid injustice to secured and unsecured creditors. As Goode explains:

\begin{abstract}
P may have good reasons for wanting proprietary protection rather than a purcly personal order for the payment of moncy; however what he now secks is not restomation of his own property but the allocation of a particular asset or collection of assets of $D$ to satisfaction of a claim for infringement of a right.... Any consiructive trust in such a case is necessarily remedial in character, and faimess to D's general credilors requires that any cosis of acquisition incurred by $D$ which $P$ has been saved should either be reimbursed as a condition of a proprietary order or deducted in measuring the sum for which $P$ is 10 be given restitution in specie. ${ }^{\text {t9 }}$
\end{abstract}

Fairness to Korkontzilas' creditors was not a concern in Soulos because Soulos was prepared to infuse the defendant's estate with a sum of money in payment for the property. ${ }^{50}$ As a result, the creditors could have no cause for complaint because the defendant's estate was put back into the position it would have been in had Korkontzilas not acted in breach of his duty of loyalty in the first place. This is an application of the principle that the defendant's creditors should not be in a better position as a result of the defendant's breach of duty. ${ }^{51}$

In sum, the facts of Soulos meet all four of Goode's necessary conditions for a proprietary remedy for equitable wrongdoing. Two points bear repeating. First, the presence of all four conditions does not entille the plaintiff to a constructive trust. The Supreme Court of Canada has stated time and again that equitable remedies are always subject to the discretion of the court. ${ }^{32}$ Prejudice to the defendant's creditors is but one situation in which a court may exereise its discretion. The second point is that not every breach of equitable duty will support a proprietary award. If the plaintiff is unable to show that the property in question would have otherwise come to her, she will be limited to a monetary award.

\title{
2. Equitable Breach Not SUPPORTING Proprietary Disgorgement
}

At first blush, it is somewhat surprising that the Court in Soulos did not cite the Privy Council's opinion in Reid. ${ }^{53}$ On the one hand, the oversight is noteworthy because Reid is an important Commonwealth case awarding proprietary disgorgement for equitable wrongdoing. On the other hand, the Supreme Court of Canada may have seen an important distinction between Soulos and Reid insofar as Soulos was a case about the proprietary disgorgement of deemed agency gains, whereas Reid involved proprietary disgorgement of a bribe. Even though the cases may be distinguished on that basis, Reid is nevertheless a leading

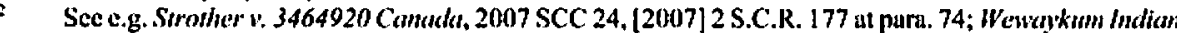
Band v. Camuda, 2002 SCC 79, [2002] 4 S.C.R. 245 at para. 107; Hodgkinson v. Simms, [1994] 3 S.C.R. 377 at 444; Canson Enterprises Lid. v. Boughton, [1991] 3 S.C.R. 534 at 587-89.

$s$

Ibid. at 226 [footnoles onitted].

Soulos, supra note 10 at para. 51 .

Goode, "Property," supra nole 37 at 226.

Supra note 20. 
Commonwealth case on gain-based proprietary awards and has recently influenced an appellate decision in this jurisdiction. ${ }^{5+1}$

In Reid, the defendant was a public prosecutor who received bribes which he used to purchase land in New Zealand. The Attorney General for Hong Kong sought an equitable interest over those lands, which had increased in value, and the Privy Council allowed the claim. Following the extrajudicial arguments of Lord Millett, the Privy Council grounded its reasons in the position that a personal award to recover the value of a bribe was limiled to the initial gain and, consequently, did not extend to any additional gains generated from the use of the bribe..$^{\text {s }}$ In order to get at the increased value of the land and enforce the high standards of a fiduciary in equity, the Privy Council held that the defendant was "accountable not only for the original amount or value of the bribe" at the point at which he accepts it in breach of his fiduciary duty, "but also for the increased value of the property representing the bribe." $"$ In doing so, the Privy Council rejected the leading English case, Listerv. Siubbs, which restricted the beneficiary's remedy to an accoumt of profits, ${ }^{57}$ stating that it "is not consistent with the principles that a fiduciary must not be allowed to benefit from his own breach of duty, that the fiduciary should account for the bribe as soon as he receives it and that equity regards as done that which ought to be done." ${ }^{38}$ Accordingly, the Privy Council decided that Reid held the bribe on constructive trust for his principal.

To further buttress its position, the Privy Council reasoned that a defendant's creditors should not be placed in a position better than the defendant. Consequently, as between the plaintiff and the defendant's creditors, the plaintiff has a better claim to the profits of a wrong. ${ }^{59}$ This position once again supports Lord Millett, who posits a policy argument, which suggests that sympathy for creditors of an insolvent fiduciary is misplaced:

Allowing a proprietary remedy merely withdraws from the insolvent's estate an asset which it was never meant to have.... Neither the fiduciary himself nor his creditors can be allowed to derive any advantage from his violation of his fiduciary duly. Better that the principal receive a windfall than that the creditors should obtain any benefit from an asset which ought never to have formed part of their debtor's estate.,

Contrary to Lord Millett's position, critics argue that proprietary rights should only be awarded where, like a secured creditor, the plaintiff has not taken the risk of the defendant's

s4 ICBC, supra note 29. Discussed in detail Part IV.C, below:

\$S Sir Peter Millett, "Bribes and Secret Commissions" [1993] R.L.R. 7 at 17 [Millstl, "Bribes"].

s6 Reid, supra note 20 at 331.

97 (1890), 45 Ch. D. 1 (C.A.).

s. Reid, supra note 20 at 336.

s* Tbid.

Millett, "Bribes," supru note 55 at 17. This position continues to prevail among the judiciary. Recently.

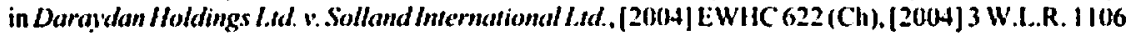
at para. 86 [Daraydan / Woldings]. Collins J. stated: "There are powerlul policy reasuns for ensuring that a fiduciary does not retain gains acquired in violation of liduciary duty, and I do not consider that it should make any difference whether the fiduciary is insolvent. There is no injustice to the ereditors in their not sharing in an assel for which the liduciary has not given value, and which the fiduciary should not have had." Significantly. Daraydan /loldings is English authority that explicitly approves and relies on the decision of the Privy Council in Reid, ihid. 
insolvency..$^{61}$ As explained above, Goode questions the assumption, which the Privy Council made in Reid, that the injured party's award should rank ahead of the interests of other creditors. He fails to see how Lord Millett's policy justification for the award of a proprietary remedy justifies why creditors should have to suffer for the fiduciary's wrongdoing. For some, "it is not clear why the sins of the debtors should be visited upon their creditors." Ultimately, the disagreement comes down to who has a greater right to the defendant's property - the plaintiff or the defendant's creditors. ${ }^{63}$

\section{Remoteness of Gain-Bastid Damages}

If proprietary disgorgement is awarded because disgorgement damages do not go far enough to strip the wrongdoer of the full extent of his gain, then it may be possible to resolve part of the problem by developing more sophisticated rules for remoteness of disgorgement damages for equitable wrongs. ${ }^{\text {to }}$ The courts have developed nuanced rules to determine which of the plaintiff's losses are the responsibility of the wrongdoer, but the same cannot be said of the rules that determine the extent of the defendant's liability to disgorge gains. On the contrary, the rules for remoteness of gains are comparatively underdeveloped. ${ }^{\text {t5 }}$ One of the main challenges in developing these rules is determining where to draw the line. Lord Millett and Birks previously argued that all claims to recover the profits of wrongdoing should be limited to the first non-subtractive receipt. ${ }^{66}$ Edelman, on the other hand, argues that courts could instead adopt a reasonable foreseeability of profits test for innocent wrongdoers (such as innocent fiduciaries). ${ }^{67}$ He further argues that it may be appropriate to have a stricter test in a situation of deliberate wrongdoing, which would capture all direct gains - even those not reasonably foreseeable. ${ }^{68}$

With a more developed understanding of the rules of remoteness damages, it may be possible to strip profits directly made from a deliberate breach and, consequently, eliminate the need for a proprietary disgorgement award in some circumstances. This solution offers a better balance between the interests of the plaintiff and the defendant's creditors, and it continues to ensure that a deliberate wrongdoer does not profit from his wrong.

Sec Burrows, Lani, supra nole 34 al 69-75; Rotherham, supra nole 13; Roy Gookle, "Proprictary Restitutionary Claims" in Cornish et al., supra note 4, 63.

Rotherham, ibid. at 179. Sec also Burrows, ibid. at 72.

There are very good reasons for denying proprietary relief and requiring the plaintifl wo lineup with other creditors. First, unlike the plaintilt, most creditors will actually sutler a loss if they are not paid. Second, many crediturs such as tort viclims are entirely involuntary. Third, even a commercial creditor may have extended credit to the defendant only because, given the defendant's possession of the wrongful gain, he appeared credit worthy.

Edelman, supra note 1 at 108-11, 263.

Charles Mitchell, "Causation, Remoteness, and Fiduciary Gains"(2006) 17 King's College Law Journal 325 at 328.

See Millett. "Bribes," supra note 55 at 17: Peter Birks. Imroduction to the Law of Restitution (Oxford: Clarendon Press, 1985) at 351-54. Lord Milletl has now acknowledged in Jones \& Sons (Truslee of r. Sones, [ [ 1997] I Ch. 159 (C.A.) that il the obligation exists (o) puy over the initial bribe, "it carries with it the duty lo pay over or account for any profits made by the use of the money" (at 167). Edelman, supro note 1 at 108. "That type of test was used in Frank Music Corp. v. Metro-GolchinnStayer, 886 F.2d 1545 (9th Cir. 1989). Cf. Mitchell, supra note 65 at 337-39.

Edelman, ibid. at 109. The law already applies a harsher remoteness rule to some types of wrongdoers. Tortfeasers guilty of deceit, lor example, are liable for all direct losses and not merely those that are reasonably foresceable. 


\section{Knowing Assistance}

The discussion to this point has focused on the availability of gain-based remedies for equitable wrongs generally. We now turn our attention to a specific form of equitable wrongdoing - knowing assistance. It should come as no surprise that a principal's most obvious course of action in the event of breach of trust or fiduciary duty is to sue the fiduciary. Very often, however, the principal may wish to sue another person who participated in the breach of duty. Most recent cases dealing with knowing assistance involve actions brought against professionals, such as accountants, financial organizations, legal professionals, and company directors, without whose "assistance" certain financial frauds may not be possible. These types of professionals and organizations are typically solvent or well-insured, which makes them attractive defendants. As we shall consider in detail below, the plaintiff may also want to sue the assistant to a breach of trust or fiduciary duty to ensure that the assistant does not profit from his wrong.

For well over a century, Lord Selbome's statement in Barnes $v . A d d v^{69}$ has been the starting point for considering the basis of equitable liability of accessories to a breach of fiduciary duty. In that case, Lord Selborne said that the liability of the trustee will be extended in equity to third parties who participate in the fraudulent conduct of the trustee. He identified three grounds upon which a stranger may be held liable as an accessory to a breach of trust: (1) as a trustee de son tort, (2) for knowing receipt of trust property, and (3) for knowing assistance in a breach of trust.

\section{A. The "Constructive" Trustee}

A source of much confusion in any area of law occurs when a single entity is known by a variety of different names. The stranger to a trust has been known variously as a dishonest assistant, an accessory to an equitable wrong, a third party to the breach of trust, and most confusingly, a constructive trustee. For the most part, those labels are self-explanatory and help situate the defendant in the legal landscape; however, the final label, "constructive trustee," provides no such assistance and, consequently, should be abandoned altogether.

The word "constructive" in this context is meant to suggest that the third party is not a genuine trustee owing the full range of a typical trustec's duties, but is meant to be treated as if he were one. "In that regard, the label "constructive trustee" is a fictional mechanism aimed at bringing the stranger into the trust relationship, which normally includes only the trustee and the beneficiary. With this mechanism in place, the beneficiary is able to claim against the stranger for his assistance in the breach of trust. This label is misleading insofar as it implies that there is the imposition of a constructive trust as opposed to the imposition of an obligation - the purpose of which is to legitimize holding the assistant accountable to the beneficiary. Such language runs the risk of confusing a constructive trustee with the 
true trustee of a constructive trust, which may lead to a proprietary remedy where only a personal one should have been available."

One reason for maintaining this misleading terminology is that it enables the courts to "preserve the orthodoxy that beneficiaries cannot sue anyone except their trustees, while simultaneously allowing beneficiaries to sue third parties such as dishonest assistants."72 In order to preserve this convention, the plaintiff must somehow draw the third party into the trust relationship even though the stranger does not hold (and possibly never held) any property on trust for the claimant. This is achieved by the legal fiction. The proposition that the third party is a trustee, which rests on an inaccurate factual basis and which purports to be a rule necessary for the resolution of the issues between the parties, is entirely unnecessary. There is no need to bring the knowing assistant within the trust relationship by artificially labelling him as a "constructive trustee" when another label exists which describes the nature of the knowing assistant's liability - that is, equitable accessory liability. ${ }^{73}$ That label clearly situates the relationship between the third party and the beneficiary in equity, indicates that the liability stems from participation in an equitable wrong, and does not create any fictional or misleading labels ${ }^{\text {it }}$ which may be misinterpreted and misapplied (intentionally or otherwise) in subsequent cases and may potentially result in a remedy that the cause of action does not support in any principled way.

\section{B. BASIS OF LIABILITY FOR KNOWING ASSISTANCE}

In Barnes, Lord Selborne identified two prerequisites for liability as a knowing assistant: first, a fraudulent and dishonest design on the part of the trustee, and second, assistance with knowledge on the part of the defendant." The leading case in Canada on liability for knowing assistance, Air Canada v. $M \& L$ Travel Lid., ${ }^{76}$ adheres to Lord Selborne's traditional formulation. Briefly put, liability for knowing assistance in Canada requires proof that (1) the defendant had actual knowledge of the underlying breach (or was reckless or wilfully blind to the facts), ${ }^{77}$ and (2) the breach of trust was part of the trustee's fraudulent and dishonest design. ${ }^{78}$ In other words, the assistant to the breach of trust need not be

"A.H. Oosterhoff et al., Ousterhoff on Trusts: Text, Commentary and Materials, Gth ed. (Toronto: Thomson Carswell, 2004) at 851.

" Charles Mitchell, "Assistance" in Petcr Birks \& Arianna Pretto, eds., Breach of Trast (Oxiord: Hart, 2002) 139 at 147, 153-54; Smilh, "Constructive Tnusts," supra note 70 at 294, 299-300.

$" \quad$ In their recent article, Steven B. Elliott and Charles Mitchell refer to this form of liability as "civil secondary liability": Steven B. Elliott \& Charles Mitchell, "Remedies for Dishonest Assistance" (2004) 67 Mod. L. Rov. 16. While their description is serviceable, it does not accurately capture the significance of the fact that liability sounds in equity.

it There is one potential problem with this label. The term "accessory" carries the connotation that the assistant is a secondary or subordinate party in the commission of the wrong. Certainly, in some situations, it will be the case that the accessory plays a willing, but secondary role in the commission of the wrong. II is equally possible, however, that the equitable accessory may be the instigator of the breach of the primary duty, which is precisely what occurred in $/ C B C$, supra note 29. For a discussion of that cast, see Part IV.C. below.

is Barnes, supra note 69 at 251-52.

[1993] 3 S.C.R. 787 [Air Comeda].

" hid. at $811-12$.

78 In Canada, there is no need to also prove that the knowing assistant acted dishonestly or in bad faith: ibid. at 825-26. There is, however, earlier Canadian authority that rejects the requirement of a dishonest or fraudulent primary wrong: Winslow v: Richter (1989), 61 D.L.R. (4th) 549 (B.C.S.C.) at 557-58. 
dishonest or fraudulent, but the breach of trust must be. There are several difficulties with this position, not the least of which is the difliculty of assessing the requisite degree of knowledge on the part of the assistant and, even more dangerous, the possibility that an assistant will escape liability where the breach of trust is an innocent one orchestrated by a dishonest third party.

Elsewhere in the Commonwealth, the law has taken a different and more preferable course. The seminal movement away from Lord Selborne's statement occurred in Royal Brunei Airlines v. Tan, ${ }^{79}$ when the Privy Council reconsidered the law of knowing assistance or, as the Committee preferred to call it, the "accessory liability principle." Lord Nicholls said that "there has been a tendency to cite and interpret and apply Lord Selborne L.C.'s formulation ... as though it were a statute. ${ }^{~} 80$ As a result of that rigid application, courts have struggled with the interpretation of the constituent elements of the cause of action, in particular "knowingly" and "dishonest and fraudulent design on the part of the trustees" and have done so "without examining the underlying reason why a third party who has received no trust property is being made liable at all."

In finding the defendant, Mr. Tan, liable for dishonest assistance, the Privy Council considered whether the breach of trust or fiduciary duty, which is a prerequisite to accessory liability, must be a dishonest and fraudulent breach. Lord Nicholls highlighted the problematic case of an innocent trustee and a dishonest third party, who assists in or procures the breach of trust. Under the Barnes formulation, the dishonest third party would be excused from liability. Lord Nicholls stated that such a result could not be right and what matters instead is the state of mind of the third party:

If the liability of the third party is tault-based, what malters is the nature of his fault, not that of the Irustet. In this regard dishonesty on the part of the third party would seem to be a suflicient basis for his liability, irrespeclive of the state of mind of the trustec who is in breach of trust. It is difficult to see why, if the third party dishonestly assisted in a breach, there should be a further prerequisite to his liability, namely that the trustee also must have been acting dishonestly. The alternative view would mean that a dishonest third party is liable if the trustec is dishonest, but if the trustec did not act dishonesily that of itself would excuse a dishonest third party from liability. That would make no sense. ${ }^{82}$

Consequently, for a third party to be liable, the Privy Council found that there must be a breach of trust or fiduciary obligation that the third party dishones $/ y$ procured or assisted, but it is not necessary also to show that the trustee acted dishonestly.

Accordingly, Lord Nicholls identified the touchstone of the assistant's liability as dishonesty, or lack of probity, which he said is synonymous. Dishonesty means not acting as an honest person would act in the same circumstances, which he said is an objective standard: 
At first sight this may seem surprising. Honesty has a connotation of subjectivity. as distinct from the objectivity of negligence. Honesty, indeed, dots have a strong subjective element in that it is a description of a type of conduct assessed in the light of what a person actually knew at the time, as distinct from what a reasonable person would have known or appreciated. Further, honesty and its counterpar dishonesty are mostly concerned with advertent conduct. not inadvertent conduct. Carclessness is not dishonesty. Thus for the most part dishonesty is to be equated with conscious impropriely. ${ }^{8.3}$

Lord Nicholls went on to identify challenging cases, such as the taking of business risks, in which it may be difficult to ascertain what honesty requires the third party to do in the circumstances. While conceding that it was impossible to describe the standard more specifically, Lord Nicholls said that Knox J. had caught the essence of it in a commercial context when he referred to a person who is "guilty of commercially unacceptable conduct in the particular context involved." 84 According to Lord Nicholls, in most cases, an honest person would have little difficulty identifying whether a proposed transaction would offend normally accepted standards of honest conduct.

The movement away from knowledge toward dishonesty as the standard of liability was authoritatively adopted in England in 2002 by the House of Lords in Twinsectra $v$. Yardley. ${ }^{85}$ The majority of the House of Lords held the view that Lord Nicholls' standard of dishonesty in Royal Brunei exemplified what has been described as a combined subjective-objective test. The majority held that, in order for liability to arise, the defendant must appreciate that his acts were dishonest by the ordinary standards of honest people. According to Lord Hutton, since a finding by a judge that the defendant was dishonest is a grave finding, particularly as against a professional, "it would be less than just for the law to permit [such] a finding ... where [the defendant] knew of the facts which created the trust and its breach but had not been aware that what he was doing would be regarded by honest men as being dishonest." ${ }^{\text {*t. }}$ The majority concluded that, since the defendant, Mr. Leach, had not realized that his behaviour transgressed the ordinary standard of honesty, he could not be held liable.

In his dissent, Lord Millett was of the view that Lord Nicholls used "dishonesty" in Royal Brumei in a purely objective sense, such that a defendant may be liable in dishonest assistance even though he does not realize that what he is doing is dishonest by the ordinary standards of honest people. Lord Milletl went on to illustrate that a combined subjectiveobjective test would produce inconsistencies between the equitable claim for dishonest assistance and its common law counterpart, the economic tort of wrongful interference with the performance of a contract. As Lord Millett noted, liability for the common law cause of action depends on the knowledge of the defendant and not on negligence or dishonesty. To impose upon the equitable claim a requirement of subjective dishonesty "introduces an unnecessary and unjustified distinction" ${ }^{17}$ that would induce "the claimant to attempt to spell a contractual obligation out of a fiduciary relationship in order to avoid the need to establish that the defendant had a dishonest state of mind." ${ }^{* 8}$ Lord Millett then stated that it would be

" hid. at $38 \%$.

×4 See Cowan de Grool Properfies Lhd. v. Eagle Trust PIc., [1902] 4 All E.R. 700 at 761.

[2002] UKHL 12, [2002] 2 A.C. 164 [Twinsectra].

thi lbid. at para. 35 .

$x$ : bid. at para. 127.

* Ibid. al para. 132. 
a reversal of the general rule that equity demands higher standards of behaviour than the common law if equity made liability dependent on subjective dishonesty when the common law did not. In the end, Lord Millett would have found Leach liable for assisting in a breach of trust. Since his lordship endorsed an objeclive approach to dishonesty, it was not necessary to consider whether Leach realized that honest people would regard his conduct as dishonest.

The majority's opinion in Twinsectra must now be read in light of Barlow Clowes International Lid. v. Eurotruss Internotional Ldd., ${ }^{\mathrm{xy}}$ in which the Lord Hoffmann clarified that he and Lord Hutton did not intend to create a combined subjective-objective test in Twinsectra. Instead, Lord Hoffman maintained that the majority's test in Twinsectra was purely objective, thus clarifying that the defendant cannot escape liability by showing that he was unaware that his actions would be considered dishonest by an objectively honest person. "Although a dishonest state of mind is a subjective mental state, the standard by which the law determines whether it is dishonest is objective. If by ordinary standards a defendant's mental state would be characterised as dishonest, it is irrelevant that the defendant judges by different standards. ${ }^{.90}$ Phrased this way, the Privy Council's opinion is more in line with Lord Millett's opinion in Twinsectra.

Regrettably, the Supreme Court of Canada adopted a completely different test in $\mathrm{Air}$. Canada.' Justice lacobucci interpreted Barnes literally and stated that a stranger will be liable if he knowingly assisted the trustee in a fraudulent or dishonest breach of trust. According to lacobucci J., "|w]hether personal liability is imposed on a stranger to a trust depends on the basic question of whether the stranger's conscience is sufficiently affected to justify the imposition of personal liability." required of the stranger, lacobucci J. explained that actual knowledge, or recklessness, or wilful blindness would suffice. ${ }^{33}$ He excluded constructive knowledge as a basis for liability because knowledge of facts that would put an honest person on inquiry "was insulficient to bind the stranger's conscience so as to give rise to personal liability." gave no guidance on how to identify these various degrees of knowledge, but even if he had done so, knowledge would nevertheless remain an unsuitable measure for defining liability. As Lord Nicholls explained in Royal Brinei:

Ibid, at para. 10.

"Significantly, there is room to cast some doubt on the authoritativeness of lacobucci J.'s lest in Air Canoda, supra note 76. Although it has been aflimed by the Supreme Court of Canada in Gold v. Rosenberg, [1997] 3 S.C.R. 767 at paras. 26-27, and purportedly applicel in Commercial Union Life Assurance Company of Canada v. Jolm Ingle Instrance Group (2002). 61 O.R. (3d) 296 (C.A.) [Commercial Union], lacobucci J.'s reasons on the nature of the breach and the test for knowledge are obiter dicta. As McLachlin J. (as she was then) pointed out in her concurring judgment. on the facts of Air Camoth, it was nol necessary lo consider whether the knowledge requirement should be determined objectively or subjectively, nor was it neeessary to consider the nature of the breach giving to liability (supra note 76 at 828-29). More recently in Simbelt Trunspors 2 . Bumeir Logissics. (2006), 17 B.L.R. (4th) 131 (Ont. Sup. Ct. J.) at para. 17. Mackenzie J. expressed coneern that the test in dir Comeda has heen applied without due regard to MeLachlin J.'s reservations. 
To inquire, in sucll cases, whether a person dishonestly assisted in what is later held to be a breach of trust is to ask a meaninglul question, which is capable of being given a meaningful answer. This is not always so if the question is posed in terms of "know ingly" assisted. Framing the question in the latter form all too often leads one into tortuous convolutions about the "sort" of knowledge required, when the truth is that "knowingly" is inapt as a criterion when applied to the gradually darkening spectrum where the differences are of degree and not kind. ${ }^{45}$

Following the English position, the preferred test for the liability of a stranger to a breach of trust is an objective one that assesses the conduct of the defendant instead of the degree of his knowledge about the underlying breach." Such a test should ask: "how would an ordinary, reasonable and honest person act in the circumstances in which the [defendant] found himself?"'? or has the defendant transgressed "ordinary standards of honest behaviour. ${ }^{, 98}$ The underlying nature of the breach should not factor into the test. The mere fact of breach - innocent or otherwise - provides a sufficient basis to support equitable accessory liability.

An objective test based on the defendant's conduct better recognizes that the claim is fault-based and the defendant is liable because he is directly at fault." In other words, liability is imposed on a person who procures or assists in the commission of an equitable wrong because his actions create a sufficient nexus between his participation and the violation of the pre-existing right of the plaintiff such that he should be jointly responsible. ${ }^{100}$ Although it is the fiduciary that owes the principal the primary duty of loyalty, the nature of the underlying relationship is such that any advertent interference with it warrants liability. As Steven B. Elliot and Charles Mitchell explain, "the defendant's liability derives from, and duplicates, the liability of the primary wrongdoer in whose acts he has participated, either by inducing the primary wrongdoer to commit them, or by conspiring with him to commit them, or by assisting in their commission."

Royal Brumei, supro note 79 at 391 . The "sonts" of knowledge that Lord Nicholls referred to are those which lad been previously sel out in Boten $x$. Société Gónérale pour Fovoriser le Développement du Commerce' et de I'Inderstrice en France S.A. [1993] I W.I.R. S09 (Ch. D.) [Baden]. In that case, Gibson J. held that any of five lypes of knowledge would suflice to make the defendant liable as an assistant to a breach of irust: (1) actual knowledge: (2) wilful shutting of one's eyes to the obvious ("Nelsonian" knowledge); (3) wilful and reckless lailure to make the inquiries that an honest and reasonable person would make; (4) knowleclge of circumstances that would indicate the lacts to an honest and reasonable person; and (S) knowledge of circumstances that would put an honest and reasonable person on inquiry (at para. 250).

The difficulty of applying lacobucci J.'s test is illustrated in Commercial Union, supra note 91. Although she purported to apply lacobucci J.'s test from Air Comada and to reject the test in Twinsectra, Weiler J.A. applied a test that focused on the defendant's subjective knowledge and conduct; Commercial Union, styra note 91 al paras. 72-73. See also M.H. Ogilvic, "(Un)knowing Assistance by the Ontario Court of Appeal," Case Comment, (2004) 40 Can. Bus. L.J. 399 at 408-409. Ogilvic, ihid. at 410.

w Mid., citing Commercial Unton, supra note 91 . Weiler J.A.

"11" Plilip Salles, "The Tort of Conspiracy and Civil Secondary Liability" (1990) 49 Cambridge L.J. 491 at 502-10; D.J. Cooper, Secondary Listhility for Civil Wrongs (Ph.D Thesis, Universily of Cambridge, 1996) [unpublished]. Compare Hazel Carty, "Joint tonfeasance and assistance liability" (1999) 19 L.S. 489. 
Another reason for imposing liability on a stranger who participates in a breach of trust or fiduciary duty is because it provides greater protection for the institutional interests underlying the cause of action. As explained above, the fiduciary relationship imposes onerous burdens on a fiduciary in order to prevent him from abusing his position and to protect the vulnerability of the beneficiary. As Hazel Carty states, "[o]ne party has trust and confidence in the other to manage his affairs, so that the relationship is afforded special protection by equity."102 Equity goes even further to safeguard this special relationship by imposing liability on an assistant who knowingly interferes with it. In other words, the instrumentalist goal of safeguarding the relationship of trust and preventing the fiduciary from breaching his duty of loyalty - innocently or otherwise - justifies liability against the advertent assistant involved with that breach. The parameters of the assistant's gain-based liability are the subject of the next section.

\section{GAIN-BASEd LiABILITY Of THE KNOWING ASSISTANT}

The secondary nature of the knowing assistant's liability helps explain why an assistant is jointly and severally liable with the fiduciary. If the plaintiff seeks a loss-based remedy, it will first be necessary for her to show that the fiduciary's breach caused her loss. However, it is not necessary for the plaintiff to show a causal link between the assistant's actions and her loss. Instead, the plaintiff need only show that there is a causal connection between the assistant's acts and the fiduciary's primary wrong. ${ }^{103}$

The situation is more complicated, however, when the plaintiff seeks a gain-based remedy from the knowing assistant. The reason is because there are two types of disgorgement claims that can lie against the knowing assistant. In the first type of case, the defendant is jointly and severally liable for the gain in the hands of the fiduciary. In the second type of case, the defendant is liable for the gain he made himself. ${ }^{114}$

\section{A. JOINT AND SEVERAL LIABILITY FOR FIDUCIARY'S GAIN}

Since the knowing assistant is jointly and severally liable with the fiduciary, the assistant is subject to the same personal liabilities as the fiduciary, which means that the knowing assistant may be required to pay over the amount of the fiduciary's gain. In other words, if the fiduciary generates a profit in breach of his duty to the principal, the knowing assistant will be personally liable for the amount of the fiduciary's gain regardless of its source. There is no shortage of cases awarding this type of gain-based recovery against the assistant. ${ }^{105}$

Carty. supra note 100 at 511 .

The leading traditional precedent for this form of liability is Mahesan v. Makaysia Governmen Officers ' Co-Opcrative /lousing Society/.td., [1978] 2 W.L.R. 444 (P.C.). criticized in A.M. Tettenbom, "Bribery, Corruption and Restitution - The Strange Case of Mr. Mahesan" (1979) 95 Law Q. Rev. 68. Ste also Morrison 1: Cocast Finance Lud. (1965). 55 D.L.R. (2d) 710 (B.C.C.A.). Sheppard J.A. [Morrison]) Casio Computer Lad. v. Sayo, [2001] EWCA Civ 661 al para. 15; Elliott \& Mitchell, supra note 73 at 18. Ellioll \& Mitchell, ibid. at 40.

Canada Sufewoy Lid. v. Thompson, [1951] 3 D.L.R. 295 (B.C.S.C.) [Canada Safeway]; Mac Donald v. Hauer (1976), 72 D.L.R. (3d) 110 (Sask. C.A.); Morrison, supra nolc 103, Sheppard J.A.; D :Imore :: McDonald, [1973] I O.R. 845 (H.C.J.), aff d (1973), I O.R. (2d) 370 (C.A.); MecMillan Bloedel litd. v. Binstead (1983), 22 B.L.R. 255 (B.C.S.C.) [MacMillan Bloedel]; Glenko Enterprises Lrd. v. Keller. 2000 MBCA 7, 150 Man. R. (2d) 1. 
In this type of situation, the gain-based award against the defendant cannot be classified as disgorgement damages in their true sense. Even though the award is quantified with reference to a gain - the fiduciary's - it is not actually stripping the gain when it is awarded against the knowing assistant. In most precedents of this nature, the courts have had little difficulty attributing liability to the assistant possibly because the assistant has benefited from the breach as well. In this situation, depriving the fiduciary corporation of the benefits of its breach also deprives the assistant directors of any benefit they would have accrued from their involvement with the scheme.

This leads us to question whether liability can or should be imposed on the knowing assistant in the absence of personal benefit. Chief Justice McLachlin raised this question in her concurring opinion in Air Canada, ${ }^{106}$ but it was unnecessary for her to answer as the defendant had in fact acquired a personal benefit. Elliott and Mitchell raise the same question in their article and suggest that holding the defendant accountable for the fiduciary's gain resembles punitive damages more so than it does disgorgement damages. ${ }^{107}$ The authors nonetheless agree that this type of gain-based remedy provides "a powerful disincentive to deter third parties from meddling in the fiduciary relationship."1t: The difficulty with classifying the award as punitive damages is that it reduces the scope of liability to those assistants who have acted in a high-handed manner. There may be circumstances in which the knowing assistant has not acted with a sufficient degree of maliciousness, but for which he should nonetheless be held jointly accountable with the false fiduciary because of his advertent involvement in the fiduciary's breach. Even if the assistant has not acquired a benefit from the breach, the need to safeguard the relationship of trust and confidence justifies this type of disgorgement award.

\section{B. Liaibility for DEFENDANT's Gains}

In addition to his liability for the fiduciary's gains, the assistant may be required to disgorge the gain that he acquired for himself as a result of his knowing assistance. In other words, if the assistant acquires a gain as a result of participating or assisting in a breach of fiduciary duty that is separate from the fiduciary's gain, the plaintiff may demand that the assistant give up the gain. Judicial authority for this type of recovery is rare. ${ }^{109}$

The challenge posed by this type of award is that it goes beyond the scope of secondary liability and imposes liability as it would upon a primary wrongdoer. As Elliott and Mitchell explain:

\footnotetext{
100 Air Canada, supra note 76 al 829-30.

107 Elliott \& Milchell, supra note 73 at 41.

108 Ibid.

Iow ICBC, supra note 29; Canada Sufewan, supra note 105: Macdillan Bloedel, supra note 105. Sec also Fy/es Group LId. v. Templeman, [2000] 2 Lloyd's Rep. 643 (Q.13.) al 660-68 (Justice Toulson indicaled in obirer dicta that a claimant could conceivably have an account of profits against a dishonest assistant who has benefited from his wrongdoing); Warman Internotional Limiledv. Dwier, [1995] HCA 18,182 C.L.R. 544 [ Wormon] (The Court held that assistant corporations knowingly profited from Mr. Dwyer's breach of fiduciary duty and, as such, were liable to account to Warman for the benefit received as a result of their participation in the breach).
} 
$[O]$ ne might justify a rule that the distonest assistant should pay over the amount of his gain in docirinal terms by saying that the dishonest assistant not only exposes the assistant to secondary civil liability, but is also an independent civil wrong which exposes him to a primary liability to pay over the amount of his own separate profits. This dual characterization of liability for dishonest assistance would be open to the charge of anomaly, since it would require us to think of the liability as secondary and duplicative for all other purposes but as primary in relation to this one head of recovery. It might be thought. however, that to apply the theory in full and leave dishonest assistants in possession of their ill-gotten gains would produce anomalies of a diflerent and more important variely. ${ }^{10}$

The desire to prevent the defendants from profiting from their wrongs was the reason given for moving beyond a "duplicative" analysis, as Elliott and Mitchell call it, and disgorging the defendant's profits in $/ C B C^{\prime \prime \prime}$ and MacMillan Bloedel. ${ }^{112}$ To do otherwise would have left profits in the hands of the knowing assistants. The problem with the duplicative analysis is that it puts forth too narrow a view of the wrong perpetrated against the plaintiff. In essence, the duplicative analysis regards the separate acts of the trustee and the assistant too narrowly as the same wrong. That is to say, despite the fact that there may be two or more wrongdoers working together to affect the breach, in the end, there is only one interference with the duty. The single interference enabled both the fiduciary and the defendant to acquire a benefit.

If, however, one considers the matter from the perspective of obligations owed to the plaintiff, it is clear that both the fiduciary and the defendant have violated separate legal obligations and, hence, each perpetrated a wrong. The fiduciary's duty constitutes the primary obligation and the defendant's obligation not to interfere with that relationship constitutes a distinct, albeit parasitic, obligation. The assistant's obligation does not exist until the primary obligation arises, but once it exists, the obligation survives on its own. Even in the absence of dishonesty on the part of the fiduciary, the defendant should, for this reason, be independently liable where he acquires a gain as a result of his wrongful interference with the primary relationship.

In the language of rights and duties, the fiduciary's duty of loyalty is the prior existing right of the beneficiary. When the fiduciary breaches his duty, the beneficiary is entitled to the fiduciary's gains because they represent the material embodiment of the breach of duty. ${ }^{.13}$ Because of the need to safeguard the vulnerability of the fiduciary relationship, the beneficiary's primary right extends beyond the fiduciary to anyone who interferes with the fiduciary's duty. It matters not that the fiduciary's breach was innocent, negligent, dishonest, or fraudulent - he would be liable in any event. However, where the assistant's involvement reaches a degree of advertence ${ }^{144}$ for which he can be held accountable, the plaintiff should be entitled to the assistant's gains, which also represent the material embodiment of the breach of (parasitic) duty. 


\section{Proprietary Remedies}

Having considered the different forms of personal liability that the knowing assistant may face, the question we now consider is whether the remedies available against the knowing assistant should extend to a proprietary claim over the gain he may have acquired. The answer to that question depends on the source of the defendant's gain.

\section{PROPRIETARY RESTITUTIONARY REMEDY}

In many instances, the defendant's gain is derived from the plaintiff's property, in which case she may have a claim in both knowing assistance and knowing receipt. ${ }^{115}$ Knowing receipt describes a situation in which the assistant to a breach of trust or fiduciary duty receives or retains property in which the beneficiary has a beneficial interest. In such circumstances the plaintiff should be entitled to the return of her property (assuming that it, or its traceable proceeds, are identifiable) for the simple reason that she continues to own the property that was wrongfully subtracted from her. ${ }^{116}$ This is a proprietary restitutionary remedy.

\section{Proprietary Disgorgement Remeidy}

More challenging is the situation in which an assistant participates in a breach of fiduciary duty such that both the fiduciary and the defendant assistant acquire deemed agency gains - that is, gains that were not subtracted from the plaintiff's estate, but that would have otherwise accrued to her but for the breach of fiduciary duty. Assuming that the plaintiff can meet the requirements set out in Soulos, ${ }^{117}$ she will be entitled to a constructive trust, subject to the discretion of the court. Moreover, in these circumstances, the assistant will be jointly and severally liable for the fiduciary's gains (which represent his secondary, personal liability), in addition to his liability for his own gains, which again, may attract a proprietary remedy.

\section{PROPRIETARY REMEDY NOT AVAILABLE}

Another set of circumstances occurs when the gains in the hands of the assistant are neither subtracted from the plaintiff's assets nor would have been received by her but for the

In Barnes, supra note 69, Lord Sclbome separated the two limbs of liability. There is little doubt that they are both forms of secondary liability; howcver, some authors such as Edelman suggest that both types of wrongdoing fall within the broader eategory of the equitable wrong of dishonest participation in breach of a liduciary duty: Edelman. supra note 1 at 57-59, 193, 198-202. See also Lord Nicholls, "Knowing Receipt: The Need for a New Landmark" in Comish ef al., supra note 4, 231 at 244 in which he states that, in the case of dishonest recipients, "[r]eceipt of property is incidental, in the sense that it is merely the form in which dishonest participation takes." Although the Court of Appenl commented on Lord Nicholls" article in Bank of Credit and Commerce International (Overseus) Lid. v. Akindele. [2001] Ch. 437 (C.A.) (speculating that strict liability for knowing receipt would be "commercially unworkable"), this issue has yet to be settled by the courts. 
breach of fiduciary duty. It was precisely this type of scenario that the British Columbia Court of Appeal was called upon to analyze in $I C B C .^{118}$

In 2004, the Insurance Corporation of British Columbia (ICBC) brought an action against several defendants for conspiring to defraud the provincial drivers licensing agency. The principal defendants were Mr. Chiu, a driving school instructor, Dragon Driving School, the company operated by Chiu, and Ms. Diaz, a driver's licence examiner and former employec of the plaintiff. In exchange for payments from Chiu, Diaz fraudulently recorded that Dragon's clients passed knowledge and road tests and fraudulently issued driver's licences to them. Diaz received CDN\$500 from the client each time she passed a client on a knowledge or road test. Chiu received payments ranging from $\$ 2,000$ to $\$ 8,000$ for each transaction.

The trial judge found that Diaz was in a position of trust and breached her fiduciary duty to her employer by accepting bribes to issue licences to persons who had not been tested or qualified to drive. Accordingly, the plaintiff was entitled to receive from any of the principal defendants disgorgement damages representing the amount of the bribes received by Diaz. (and for which Chiu would be secondarily liable). However, the trial judge refused to award disgorgement damages against Chiu for the sums he received from his clients (which would represent Chiu's primary liability). It followed, therefore, that the plaintiff was not entitled to trace Chiu's profits into asscts held by his wife, Ms. Lo. According to Groberman J., since Chiu did not owe a duty of utmost good faith to the plaintiff, there was no basis upon which to grant a proprietary remedy to capture his profits and, as such, "the plaintiff's claim to trace funds into the hands of Ms. Lo must fail." 119

ICBC appealed the trial decision because it feared that it would be without an effective remedy in the absence of a constructive trust. Consequently, the British Columbia Court of Appeal revisited the question of whether ICBC could claim a gain-based remedy against Chiu for the amount he received from his clients over and above the funds he paid to Diaz. Relying on MacMillan Bloedel, ${ }^{120}$ the Court found that the knowing assistant was accountable to the same standards as the false fiduciary. As a result, there is no need for the plaintiff to show that the defendant's wrongdoing caused a loss. ${ }^{121}$ The Court of Appeal went on to find that the plaintiff was entitled to proprietary gain-based relief based on the Supreme Court of Canada's reasons in Soulos. ${ }^{122}$

The Court of Appeal acknowledged that Sowlos was not a case of knowing assistance and that the Supreme Court was not called upon to decide whether a proprietary disgorgement remedy was available against a knowing assistant. Nevertheless, the Court of Appeal relied on a passage in Soulos in which McLachlin J. (as she then was) referred to MacMillan Bloedel, a knowing assistance case, to support its position that a constructive trust is a remedy available against a knowing assistant. In particular, Rowles J.A. cited the passage from Soulos in which the majority stated that a constructive trust may be imposed on a

ICBC: supra note 29.

Insurance Corp. of British Columbia v: Dragon Diving School Camada Lad. 2005 BCSC 1093, 43

B.C.L.R. (4th) 330 at paras. $20,23$.

Supra note 105.

$I C B C$, supra note 29 at paras. $46-48$.

See discussion of Soulos in Part II.C. ., above. 
knowing assistant "not to balance the equities but to ensure that trustees and fiduciaries remain faithful and that those who assist them in the breaches of their duty are called to account." 123 In the end, the Court of Appeal granted a constructive trust over the traceable funds that Chiu received from his clients because that remedy was in keeping with the approach to constructive trusts that the majority set out in Sollos.

The Court of Appeal's reasons for imposing a constructive trust are problematic in several ways. First, the Court of Appeal places unwarranted reliance on the Supreme Court of Canada's approval of MacMillan Bloedel. The majority in Soulos cited MacMillan Bloedel to illustrate the point that constructive trusts could be imposed in situations where the elements of the cause of action in unjust enrichment were not all present. In other words, the Court did not fully analyze or make a finding that a constructive trust is an appropriate remedy as against a knowing assistant. The reference to MacMillan Bloedel was simply one of several cases that the majority catalogued to show that constructive trusts have been awarded in the absence of unjust enrichment. Had the Supreme Court considered the matter, it may well have come to the conclusion that a proprietary disgorgement remedy is not a proper form of recovery against a knowing assistant.

The passage from MacMillan Bluedel that McLachlin J. (as she then was) relied upon is misleading insofar as it conflates two distinct uses of the term "constructive trust." If we examine the larger context of the passage, we see that Dohm J. (as he then was) explained that equity imposes a constructive trust in at least two different situations, the first of which is to prevent unjust enrichment as suggested by Dickson J. in Pettkus. ${ }^{124}$ Justice Dohm went on to explain the second situation as follows:

The second type of constructive trust is that relerred to in Barnes 1. Addy and the eases which preceded and followed it. This type of trust is imposed even when the Plaintiff has suffered no loss or deprivation. It is inposed not to balanee the equities but to ensure that truslees and fiduciaries remain faith ful and that those who assist them in the breaches of their duty are called to account. ${ }^{125}$

From this passage we see that Dohm J. made the perennial error of concluding that a constructive trust is an available remedy because the defendants were "constructive trustees." As discussed above, ${ }^{126}$ the label "constructive trustee," as used in Barnes, is a fictional mechanism - the purpose of which is to bring the stranger into the trust relationship and enable the beneficiary to claim against the stranger for his assistance in the breach of trust or fiduciary duty. Justice Dohm's explanation reveals the danger of the use of such terminology. He erroneously concluded that those who assist in the breaches of trust and fiduciary duty are susceptible to the same form of liability as the fiduciary - that is, the imposition of a constructive trust. Barnes does not support that conclusion. It follows, therefore, that the authority upon which the British Columbia Court of Appeal relied to award a proprietary disgorgement remedy against Chiu warrants questioning.

1: $/ C B C$ : supra note 29 at para. S6, citing Soulos, supra note 10 al para. 42, citing Mtac Millow Bloedel. supro note 105 at 287 [cmphasis added].

124 Supra note 7.

12: Mac. Millan Bloedel, supra note 105 at 287.

i: Part II.A. 
Putting aside any references to MacMillan Bloedel, Soulos provides other reasons that indicate that the Supreme Court of Canada is unlikely to suppon a claim for proprietary disgorgement against a knowing assistant. It will be recalled that the majority of the Court relied on Goode's prerequisites for the imposition of a constructive trust. Following Goode's theory, the plaintiff will be entitled to a proprictary disgorgement remedy when the defendant acquires an enrichment directly from the plaintiff's estate or in the case of deemed agency gains. Significantly, however, the plaintiff should not be entitled to a proprictary disgorgement remedy when the defendant's gain results from an activity that he should have never undertaken at all. The reason, once again, is because the benefit in the hands of the defendant is not something that would ever have come into the hands of the plaintilf under any stretch of the imagination. To give the plaintiff a proprietary interest in such circumstances would displace unsecured creditors who have given value in favour of the plaintiff who has not. It follows, therefore, that where a knowing assistant has received funds from a third party to bribe a fiduciary to breach her duty, the plaintiff should not have a proprietary claim to those funds. ${ }^{27}$ In such circumstances, the plaintiff should be limited to monetary relief, which would leave the priority of any creditors intact.

The plaintiff may complain, as ICBC did, ${ }^{12 x}$ that absent a constructive trust, the plaintiff will be without an effective remedy. While that unfortunate set of circumstances may provide a legitimate reason for seeking a proprictary remedy (one of the other prerequisites from Soulos), it is not a sufficient basis upon which to grant such a remedy. Before the plaintiff can make a case for a constructive trust, she must first establish that the property she wishes to be held on trust was subtracted from her estate or was some form of deemed agency gain. which the plaintiff cannot establish in circumstances where the defendant's bribe issues from a third party.

\section{Concuusion}

The cause of action in knowing assistance supports a gain-based response because the knowledge requirement ensures that the assistant's participation in the breach is deliberate. Moreover, the prophylactic protection traditionally afforded to the fiduciary relationship justifies a potent deterrent mechanism, which is achieved through an award of disgorgement damages. As such, the knowing assistant is made jointly and severally liable for the fiduciary's gains, but also liable for any gains he acquires in the course of the breach. To do otherwise would allow the knowing assistant to get away with schemes like the one in $I C B C$. As that case illustrates, a stranger to the equitable relationship can be wholly instrumental in perpetrating a wrong against the plaintiff. If the knowing assistant is left with the spoils of his wrong, incentive remains to perpetrate similar schemes.

Importantly, however, the need to ensure that the defendant does not profit from such activity does not, in itself, create a proprietary right. Where the plaintiff is unable to point to either a subtractive enrichment or a deemed agency gain, then she cannot establish a sufficient nexus for the imposition of a proprietary remedy. 